\title{
The effect of type of additive on rumen fermentation and digestion of grass silage in cattle
}

\author{
AIla Vanhatalo, Tuomo VarvikKo and Ilmo Aronen
}

Vanhatalo, A., VARViKKo, T. \& Aronen, I. 1992. The effect of type of additive on
rumen fermentation and digestion of grass silage in cattle. Agric. Sci. Finl. 1:163-
175. (Agric. Res. Centre of Finland, Inst. Anim. Prod., SF-31600 Jokioinen, Finland.)

Four grass silages made from a second cut cocksfoot-timothy grass were ensiled with the application of water, i. e., without additive (NA), formic acid (FA), lignosulfonate + formic acid + acetic acid (LFA) and cellulase + glucose oxidase enzymes (E). The silages were fed at maintenance level to four dry cows, which had been equipped with a rumen cannula and a simple $\mathrm{T}$-shaped duodenal cannula, in a digestibility experiment designed as a $4 \times 4$ latin square. The silages and a mixture of barley and oats $(1: 1)$ were given at a ratio of 70:30 on a dry matter basis.

All the silages were well preserved, but fermentation in the silo was more restricted in silages ensiled with acid-based additives. The enzyme treatment resulted in reduced levels of cell wall contents compared to the other silages. The apparent digestibilities of organic matter $(\mathrm{OM})$ and neutral detergent fibre with $\mathrm{E}$ silage were higher $(\mathrm{P}<0.05)$ than with the other silages. The microbial $\mathrm{N}$ flow at the duodenum was significantly higher $(\mathrm{P}<0.001)$ with the LFA diet compared to the other diets (NA 52; FA 53; LFA 66 and $\mathrm{E} 47 \mathrm{~g} \mathrm{~N} / \mathrm{d}$ ) and the efficiency of microbial protein synthesis tended to be lower with the E diet compared to the other diets (NA 31; FA 31; LFA 38 and E $20 \mathrm{~g} \mathrm{~N} / \mathrm{OM}$ apparently digested in the rumen).

The molar proportion of acetate in the rumen was significantly higher $(\mathrm{P}<0.001)$ and the proportion of propionate significantly lower $(\mathrm{P}<0.001)$ with acid silages than with $\mathrm{E}$ and NA silages. The proportion of butyrate was significantly higher with $\mathrm{E}$ silage compared to the others.

Key words: enzymes, acids, microbial protein, rumen degradation, mobile bag

\section{Introduction}

Ensiling grass into silage aims at maintaining the high nutritional value of original grass. This can be done using acids to create an environment with a sufficiently low $\mathrm{pH}$ within a short period of time to stagnate the biological activities in the grass. Alternatives to acid additives include so-called biological additives, e.g. lactic acid bacteria or fibre degrading enzymes, which develop an acidic environment through fermentation during the ensiling.
In Finland acid-based additives have been predominantly used during the past few decades in silage making to ensure sufficiently good grass silage for high-quality milk products, even for cheese making. However, as acid additives are corrosive to machinery and not user-safe, there is an increasing tendency to reduce the use of acids in silage making by replacing them with biological additives.

Thus, a number of trials have been carried out to study the response of cattle to grass silages preserv- 
ed using biological or acid-based additives (e.g. GORDON 1989, HEIKKILÄ et al. 1989, JAAKKOLA and HUHTANEN 1990, JAAKKOLA et al. 1990, KenNEDY 1990, HEIKKILÄ et al. 1991). However, there are only few reports (JAAKKOLA et al. 1991, JACOBS and MCALLAN 1991, van VUUREN et al. 1991) comparing the digestibility and rumen fermentation patterns of grass silage preserved with acid and biological additives. The purpose of the present experiment was to compare digestibility, rumen fermentation, and ruminal and intestinal degradability of grass silages preserved with acid or biological additives.

\section{Material and methods}

\section{Experimental silages}

The experimental silages were prepared from a second cut cocksfoot (Dactylis glomerata)-timothy (Phleum pratense) grass by a flail harvester using:

- no additive (NA)

- AIV-2 (Valio Finnish Co-operative Dairies' Association) $5.5 \mathrm{l} / \mathrm{t}$, containing $80 \%(\mathrm{w} / \mathrm{w})$ formic acid and $2 \%$ orthophosphoric acid (FA)

- Farmi-solution (Farmos-Group Ltd.) 5,6 1/t, containing $50 \%$ lignosulphonate, $25 \%$ formic acid and $25 \%$ acetic acid (LFA)

- Clampzyme (Finnish Sugar Ltd.) 0.2 1/t, containing cellulase and glucose oxidase enzymes (E)

All the additives were applied by a pressure pump at cutting using the application rates recommended by the manufacturers. The silages were ensiled in fibreglass silos of $3 \mathrm{~m}^{3}$ for seven months.

\section{Animals and their feeding}

The four non-pregnant and non-lactating cows (live weight $550 \mathrm{~kg}$ ) of Finnish Ayrshire breed used in the experiment were equipped with a rumen cannula and a simple T-piece duodenal cannula. The animals were fed in a balanced $4 \times 4$ latin square close to maintenance level (SALO et al. 1982), the diets consisting of experimental grass silages supplemented with a mixture of barley and oats
(1:1). The ratio of forage to concentrate was 70:30 on a dry matter (DM) basis. The animals were fed twice daily in equal amounts at $12 \mathrm{~h}$ intervals. A commercial mineral supplement was included in the diet and water was freely available.

\section{Experimental procedures}

The length of each experimental period was 28 days with a 10-day adaptation period. Representative samples of the grass silages and concentrate mix were obtained from each experimental period.

The flow of nutrients to the small intestine was estimated using the graphic alternative (MCALLAN and SMITH 1983) of the double-marker method (FAICHNEY 1975). Cr-mordanted straw and LiCoEDTA prepared as described by UDÉN et al. (1980) were used as a marker for the solid and liquid phase of digesta. Cr-mordanted straw was administered to the rumen from day 8 twice a day $(2 \times 7.5 \mathrm{~g})$ and LiCo-EDTA $(5 \mathrm{~g} / \mathrm{d})$ was infused continuously into the rumen from day 9 onwards.

Duodenal digesta was spot-sampled on days 17, 18 and 19. Samples $(150 \mathrm{ml})$ were collected at three hours' intervals, four times a day, starting at 8,9 and 10 o'clock on consecutive collection days. The spot samples of each animal were pooled to provide one composite unrepresentative digesta sample. One half of this sample was centrifuged ( $700 \mathrm{x} g / 10$ $\min$ ) to separate the particulate and liquid phases. The particulate phase and the other half of the digesta sample were dried at $60{ }^{\circ} \mathrm{C}$ and milled to pass a $1 \mathrm{~mm}$ screen. The liquid phase was stored at $-20{ }^{\circ} \mathrm{C}$ before analysis.

In order to determine the overall digestibility of nutrients using acid-insoluble ash as a natural marker, faecal grab samples were taken twice a day from day 14 to day 18 when feeding the animals.

To estimate the rumen liquid outflow rate, a single dose of LiCo-EDTA ( $8 \mathrm{~g}$ ) was infused into the rumen during one feeding interval. The infusion was started at evening feeding on day 19 and continued till the next morning feeding. On day 20, the ruminal and duodenal digesta samples were collected before morning feeding and at 1.5 hours' 
intervals thereafter during the daytime feeding cycle. The liquid phase of the samples was separated and stored as described above.

Nitrogen of microbial origin in duodenal $\mathrm{N}$ was measured using purine bases of nucleic acids as markers (ZINN and OwENs 1986). The contents of the purine bases in the microbial mass were analyzed from the rumen samples collected on day 21 immediately before morning feeding and four hours thereafter. The microbial mass was isolated by separating the rumen liquid as described earlier and by further centrifuging $(26000 \mathrm{x} \mathrm{g} / 20 \mathrm{~min})$ the supernatant.

To measure rumen fermentation, samples of rumen fluid were collected on day 21 right before feeding and $0.5,1,2,3,4,6,8$ and $10 \mathrm{~h}$ after feeding. The ammonia- $\mathrm{N}$ and $\mathrm{pH}$ of the digesta were measured immediately, and samples for the measurement of volatile fatty acids (VFA) were storaged with $\mathrm{Ag}_{2} \mathrm{O}$ in a refrigerator for later analysis.

To determine the rumen degradability and subsequent intestinal degradability of the experimental silages, nylon bag techniques were used. Each experimental silage was incubated in the animal fed with that particular silage diet. Five nylon bags ( 60 x $120 \mathrm{~mm}$ ) made of polyester (PES $41 \mu \mathrm{m} / 33 \%$, Polymon, Switzerland) containing fresh, chopped $(<10 \mathrm{~mm})$ silage $(2.5 \mathrm{~g} \mathrm{DM})$ were inserted into the rumen on day 14 and incubated for periods of 2,4 , $8,16,24,48,72$ and $96 \mathrm{~h}$. After removal, the bags were machine-washed and dried at $60{ }^{\circ} \mathrm{C}$ in a forced-draught oven.

Fifteen mobile bags ( $35 \times 50 \mathrm{~mm}$, PES $10 \mu \mathrm{m} / 2$ $\% / C$ ) per experimental silage were introduced into the duodenum from day 14 onwards. Each bag contained $0.8 \mathrm{~g}$ DM freeze-dried or rumen-incubated $(30 \mathrm{~h})$ silage, that was milled through a $2 \mathrm{~mm}$ mesh. One animal received a maximum of 20 mobile bags per day. Subsequently, the bags were collected from the faeces and machine-washed $\left(40{ }^{\circ} \mathrm{C}\right)$ and dried at $60{ }^{\circ} \mathrm{C}$.

\section{Chemical analyses}

The DM content of the grass silages was determined by oven-drying $\left(105^{\circ} \mathrm{C}\right)$, correcting the values for volatile losses according to HUIDA et al. (1986). Organic matter (OM) content was measured by ashing at $500{ }^{\circ} \mathrm{C}$ for $2 \mathrm{~h}$ and total $\mathrm{N}$ by the Kjeldahl method. Determinations of neutral detergent fibre (NDF) and acid detergent fibre (ADF) were made according to VAN SOEST (1963) and VAN SOEST and WINE (1967), calculating the content of hemicellulose as the difference between NDF and ADF and the content of lignin as the difference between ADF and cellulose. Experimental silages as well as rumen liquor and the liquid phase of duodenal digesta were analyzed for ammonia-N (McCullough 1967). Silages and rumen liquor were further analyzed for VFAs (HUIDA 1973). Also the lactic acid concentration (BARKER and SUMMERSON 1941) and water soluble carbohydrates (WSC) (SOMOGY 1945) in the silages were measured. Nucleic acids in the microbial fraction and duodenal digesta were determined according to ZINN and OWENS (1986). Chromium and cobalt concentrations in faecal and digesta samples were determined by atomic absorption spectrophotometry (Williams et al. 1962). Faecal samples were analyzed also for acid-insoluble ash (VAN KEULEN and Young 1977).

\section{Calculations and statistical analysis}

The duodenal flow of nutrients was calculated based on the amounts of $\mathrm{Co}$ and $\mathrm{Cr}$ excreted in faeces. The liquid outflow rate from the rumen was calculated as the slope of the regression of the natural logarithm of the Co concentration against time. The total outflow of liquid at the duodenum was calculated as the difference between total digesta flow and DM flow. The estimate of rumen volume was calculated as total outflow (1)/[liquid dilution rate $(1 / \mathrm{h}) \times 24(\mathrm{~h})]$.

The rumen degradability of feed $\mathrm{N}$ in vivo was estimated by assuming an endogenous $\mathrm{N}$ flow of 15 $\%$ of the duodenal $\mathrm{N}$ flow (TAmminga et al. 1989).

To characterize the rumen degradability of the experimental silages, their degradability values were fitted in to the following equations (McDoNALD 1981): 
$p_{1}=a^{\prime}$ up to time $t_{\mathrm{o}}$

$p_{2}=a+b\left(1-\mathrm{e}^{-\mathrm{ct}}\right)$ from time $t_{\mathrm{o}}$ onwards,

where $a^{\prime}$ represents the rapidly degradable fraction of the feed during the washing (' $0 \mathrm{~h}$ wash'), $p_{2}$ is the proportionate disappearance of feed after time $t(\mathrm{~h})$ $\left(t>\mathrm{t}_{\mathrm{o}}\right)$ and $a, b$ and $c$ are the constants for the instantly degradable and slowly degradable fraction of the feed and rate of degradation of the latter from time $t_{\mathrm{o}}$ onwards. The lag time, $t_{\mathrm{o}}$, was calculated as: $t_{\mathrm{o}}=1 / c \ln \left[b /\left(a+b-a^{\prime}\right)\right]$.

The values obtained for $\mathrm{N}$ were corrected for microbial contamination as suggested by LINDBERG (1988).

The total tract degradability (TTD) of the feeds was calculated as a sum of the 30 -h ruminal degradation and the subsequent intestinal degradation of the undegraded feed residue.

The standard analysis of variance appropriate to the latin square design was applied to digestibility and nylon bag data using the Tukey's test for treatment comparisons.

Rumen fluid data was analyzed by analyses of variance using the following model:

$y_{\mathrm{ijklm}}=\mu \ldots+\mathrm{A}_{\mathrm{i}}+\mathrm{P}_{\mathrm{j}}+\mathrm{T}_{\mathrm{k}}+\mathrm{e}_{\mathrm{ijk}}+\mathrm{H}_{\mathrm{l}}+\mathrm{AH}_{\mathrm{il}}+\mathrm{PH}_{\mathrm{j} 1}+$ $\mathrm{TH}_{\mathrm{kl}}+\mathrm{e}_{\mathrm{ijklm}}$,

where $\mathrm{A}, \mathrm{P}, \mathrm{T}$ and $\mathrm{H}$ stand for the effects of animal, period, treatment and sampling time, respectively, and $\mathrm{e}_{\mathrm{ijklm}}$ the residual error term. $\mathrm{e}_{\mathrm{ijk}}$ was used as an error term for testing the main effects $\mathrm{A}, \mathrm{P}$ and $\mathrm{T}$.
Dilution rate data were analyzed using the same model as with rumen fluid data, with the exception that the effect of sampling site replaced sampling time in the model. Tukey's test was used for the comparison of the treatments.

Table 2. The fermentation characteristics of the silages preserved with different additives.

\begin{tabular}{lrrrrr}
\hline & \multicolumn{3}{c}{ Silage additive } & & Grass \\
\cline { 2 - 4 } & NA & FA & LFA & E & \\
\hline pH & 4.1 & 4.2 & 4.1 & 4.1 & \\
& & & & & \\
In dry matter & & & & & \\
(g/kg dry matter) & & & & & \\
WSC & 18 & 89 & 18 & 24 & 91 \\
Lactic acid & 92 & 11 & 60 & 86 & \\
Acetic acid & 14 & 7 & 20 & 10 & \\
Formic acid & - & 21 & 8 & - & \\
Total acids & 106 & 39 & 88 & 96 & \\
Ethanol & 5 & 11 & 19 & 8 & \\
& & & & & \\
Lactic/Acetic & 6.9 & 1.7 & 3.1 & 8.6 & \\
& & & & & \\
In total N (g/kg) & & & & & \\
$\quad$ Ammonia N & 47 & 18 & 45 & 55 & \\
Soluble N & 541 & 432 & 467 & 499 & 22 \\
\hline
\end{tabular}

For silage additives, see text.

WSC, water soluble carbohydrates.

None of the silages contained propionic or butyric acid.

Table 1 . The chemical composition ( $\mathrm{g} / \mathrm{kg}$ dry matter) of the silages, grass and concentrate.

\begin{tabular}{|c|c|c|c|c|c|c|}
\hline & \multicolumn{4}{|c|}{ Silage additive } & \multirow[t]{2}{*}{ Grass } & \multirow{2}{*}{$\begin{array}{l}\text { Concen- } \\
\text { trate }\end{array}$} \\
\hline & $\mathrm{NA}$ & FA & LFA & $\mathrm{E}$ & & \\
\hline Dry matter, g/kg & 177 & 196 & 175 & 187 & 173 & 888 \\
\hline Ash & 100 & 93 & 99 & 95 & 95 & 28 \\
\hline Nitrogen & 28 & 28 & 29 & 28 & 27 & 19 \\
\hline NDF & 531 & 541 & 541 & 508 & 589 & 269 \\
\hline $\mathrm{ADF}$ & 320 & 319 & 319 & 299 & 305 & 90 \\
\hline Cellulose & 280 & 280 & 279 & 260 & 262 & 70 \\
\hline Hemicellulose & 211 & 221 & 221 & 207 & 284 & 179 \\
\hline Lignin & 40 & 39 & 40 & 40 & 43 & 20 \\
\hline
\end{tabular}

For silage additives, see text.

NDF, neutral detergent fibre; ADF, acid detergent fibre. 


\section{Results}

\section{Chemical composition and fermentation of the silages}

The chemical composition (Table 1) and fermentation (Table 2) of the silages were clearly affected by the additive used. The DM content was highest in FA silage, and E silage had the lowest contents of cell walls. Compared with E and NA silages, fermentation was restricted during ensiling by the acid-based additives, particularly FA. The content of WSC in FA silage was close to that in original grass, and ammonia- $\mathrm{N}$ and total acid content was low compared with the other silages.

\section{Intake and digestion of organic matter and fibre}

There was no difference $(\mathrm{P}>0.05)$ in $\mathrm{OM}$ intake or in faecal OM between the silages (Table 3). However, compared with the other silages, the amount of $\mathrm{OM}$ entering the duodenum was lower $(\mathrm{P}<0.01)$ in E silage and the microbial OM higher $(\mathrm{P}<0.001)$ in LFA silage. Digestibility of $\mathrm{OM}$ in the rumen, disappearance of digestible $\mathrm{OM}$ before the intes-

Table 3. The effect of silage additive on organic matter $(\mathrm{OM})$ and cell wall digestion.

\begin{tabular}{|c|c|c|c|c|c|c|}
\hline Silage additive... & NA & FA & LFA & E & SEM & $\begin{array}{l}\text { Statistical } \\
\text { significance } \\
\text { of additive }\end{array}$ \\
\hline \multicolumn{7}{|l|}{ Organic matter (g/24h) } \\
\hline In feed & 4633 & 4714 & 4886 & 4746 & 67.9 & NS \\
\hline At duodenum & $2907 \mathrm{~b}$ & 2994 b & $3101 \mathrm{~b}$ & 2339 a & 80.7 & *** \\
\hline Microbial OM§ & $580 \mathrm{a}$ & 590 a & $729 \mathrm{~b}$ & $520 \mathrm{a}$ & 18.3 & *** \\
\hline In faeces & 1040 & 1078 & 1127 & 978 & 31.9 & NS \\
\hline \multicolumn{7}{|c|}{ Digestibility in the rumen } \\
\hline Apparent & $0.370 \mathrm{a}$ & $0.366 \mathrm{a}$ & $0.364 \mathrm{a}$ & $0.510 \mathrm{~b}$ & 0.0227 & ** \\
\hline True $\dagger$ & 0.496 a & 0.493 a & 0.512 a & $0.619 b$ & 0.0213 & $*$ \\
\hline \multicolumn{7}{|c|}{ Disappearance of digestible } \\
\hline \multicolumn{7}{|c|}{ OM before intestine } \\
\hline Apparent & $0.477 \mathrm{a}$ & $0.476 \mathrm{a}$ & $0.473 \mathrm{a}$ & $0.642 \mathrm{~b}$ & 0.0293 & * \\
\hline True & $0.640 \mathrm{a}$ & $0.640 \mathrm{a}$ & $0.666 \mathrm{ab}$ & $0.779 \mathrm{~b}$ & 0.0275 & * \\
\hline Apparent digestibility & 0.774 & 0.771 & 0.769 & 0.794 & 0.0052 & $*$ \\
\hline \multicolumn{7}{|c|}{ Neutral detergent fibre $(\mathrm{g} / 24 \mathrm{~h})$} \\
\hline In feed & $2253 \mathrm{ab}$ & $2329 \mathrm{ab}$ & $2441 \mathrm{~b}$ & $2230 \mathrm{a}$ & 41.9 & * \\
\hline At duodenum & 675 & 697 & 711 & 561 & 32.8 & NS \\
\hline In faeces & 586 & 595 & 615 & 516 & 23.4 & NS \\
\hline \multicolumn{7}{|l|}{ Digestibility } \\
\hline Rumen & 0.699 & 0.699 & 0.708 & 0.750 & 0.0109 & * \\
\hline Total & 0.738 & 0.743 & 0.747 & 0.769 & 0.0093 & NS \\
\hline \multicolumn{7}{|l|}{ Total digestibility } \\
\hline Hemicellulose & 0.709 & 0.717 & 0.710 & 0.741 & 0.0101 & NS \\
\hline Cellulose & 0.799 & 0.798 & 0.815 & 0.823 & 0.0100 & NS \\
\hline
\end{tabular}

For silage additives, see text.

$\S$ Assuming a N:OM ratio of microbial matter 0.09 (CZERKAWSKI 1986).

$\dagger$ Corrected according to microbial organic matter.

a,b Means in the same row with different superscripts were significantly different $(\mathrm{P}<0.05)$.

NS, not significant; ${ }^{*}, \mathrm{P} \leq 0.05 ;^{* *}, \mathrm{P} \leq 0.01 ;{ }^{* * *}, \mathrm{P} \leq 0.001$. 
tine, and apparent total OM digestibility were highest $(\mathrm{P}<0.05)$ with $\mathrm{E}$ treatment. The intake of NDF and ADF (data not shown) was lower and their digestion in the rumen or in the total tract tended to be higher with E-treated silage than with the other silages (Table 3). Total digestibility of hemicellulose and cellulose tended to be highest with $\mathrm{E}$ treatment as well.

\section{Intake and digestion of nitrogen}

Nitrogen intake, faecal $\mathrm{N}$ and apparent digestibility of $\mathrm{N}$ were similar $(\mathrm{P}>0.05)$ for all the diets (Table 4). Non-ammonia- $\mathrm{N}(\mathrm{NAN})$ and feed $\mathrm{N}$ entering the small intestine were lower $(\mathrm{P}<0.05)$ for $\mathrm{E}$ treatment as compared with the others, while microbial $\mathrm{N}$ was highest $(\mathrm{P}<0.001)$ and microbial $\mathrm{N}$ synthesis most efficient $(\mathrm{P}<0.05)$ for LFA treatment. Silage$\mathrm{N}$ degradability was lowest in FA silage.

\section{Ruminal and intestinal degradability of silages}

Except for the potential degradability $(a+b)$ of cell walls $(\mathrm{P}<0.05)$, no statistically significant differences were found between the silages in the constants describing the degradability of OM, NDF or $\mathrm{N}$ in the rumen. However, there was a tendency towards lower $a$ and higher $b$ values, and effective protein degradability (EPD) was always lower for silages ensiled with acid-based additives (Table 5). The correction of EPD values for microbial protein according to LINDBERG (1988) increased all the values notably, the EPD for FA silage being significantly $(\mathrm{P}<0.001)$ lower than that of the other silages.

No statistically significant differences $(\mathrm{P}>0.05)$ were found in lag time, 30-h rumen degradation, intestinal degradation, or total degradation of the nutrients between the silages.

Table 4. The effect of silage additive on $\mathrm{N}$ intake, flow of $\mathrm{N}$ to the duodenum and efficiencies of microbial protein synthesis.

\begin{tabular}{|c|c|c|c|c|c|c|}
\hline Silage additive... & NA & FA & LFA & $\mathrm{E}$ & SEM & $\begin{array}{l}\text { Statistical } \\
\text { significance } \\
\text { of additive }\end{array}$ \\
\hline \multicolumn{7}{|l|}{ Nitrogen (g/24h) } \\
\hline In feed & 127 & 129 & 138 & 132 & 2.6 & NS \\
\hline \multicolumn{7}{|l|}{ At duodenum } \\
\hline Total-N & $174 \mathrm{~b}$ & $179 \mathrm{~b}$ & $188 \mathrm{~b}$ & $138 \mathrm{a}$ & 5.1 & $* *$ \\
\hline Ammonia- $\mathrm{N}$ & 4 & 5 & 6 & 3 & 0.5 & NS \\
\hline NAN & $169 \mathrm{~b}$ & $174 \mathrm{~b}$ & $182 \mathrm{~b}$ & $135 \mathrm{a}$ & 5.0 & $* *$ \\
\hline Microbial N & $52 \mathrm{a}$ & $53 \mathrm{a}$ & $66 \mathrm{~b}$ & $47 \mathrm{a}$ & 1.7 & $* * *$ \\
\hline Feed N§ & $91 \mathrm{~b}$ & 94 b & $89 \mathrm{~b}$ & $67 \mathrm{a}$ & 4.5 & $*$ \\
\hline In faeces & 30 & 32 & 32 & 30 & 1.3 & NS \\
\hline Apparent digestibility & 0.762 & 0.753 & 0.765 & 0.772 & 0.0090 & NS \\
\hline Silage-N degradability & 0.284 & 0.271 & 0.353 & 0.492 & 0.0050 & $*$ \\
\hline $\mathrm{NAN}$ at duodenum $/ \mathrm{N}$ intake & $1.34 \mathrm{~b}$ & $1.35 \mathrm{~b}$ & $1.32 \mathrm{~b}$ & $1.02 \mathrm{a}$ & 0.005 & $*$ \\
\hline Microbial $\mathrm{N} \mathrm{g} / \mathrm{kg}$ OMADR $\dagger$ & $31 \mathrm{ab}$ & $31 \mathrm{ab}$ & $38 \mathrm{~b}$ & $20 \mathrm{a}$ & 2.5 & $*$ \\
\hline Microbial $\mathrm{N} \mathrm{g} / \mathrm{kg}$ OMTDR $\ddagger$ & $23 \mathrm{~b}$ & $23 \mathrm{~b}$ & $26 \mathrm{~b}$ & $16 \mathrm{a}$ & 1.3 & $* *$ \\
\hline Microbial $\mathrm{N} \mathrm{g} / \mathrm{kg}$ DCHO $f$ & $19 \mathrm{~b}$ & $19 \mathrm{~b}$ & $23 \mathrm{c}$ & $16 \mathrm{a}$ & 0.5 & $* * *$ \\
\hline
\end{tabular}

For silage additives, see text.

$\S$ assuming endogenous flow of $\mathrm{N}$ to be $15 \%$ of duodenal $\mathrm{N}$ flow (Tamminga et. al. 1989).

$\dagger$ Organic matter apparently digested in the rumen.

$\ddagger$ Organic matter truly digested in the rumen.

$f$ Digestible carbohydrates.

a,b Means in the same row with different superscripts were significantly different $(\mathrm{P} \leq 0.05)$.

NS, not significant; ${ }^{*}, \mathrm{P} \leq 0.05 ;{ }^{* *}, \mathrm{P} \leq 0.01 ;{ }^{* * *}, \mathrm{P} \leq 0.001$. 
Table 5. The rumen degradation characteristics ( $a$, constant for the instantly degradable fraction; $b$, constant for the slowly degradable fraction; c, rate of degradation of b) of silage organic matter, neutral detergent fibre and nitrogen and intestinal degradation of their rumen undegraded feed residues.

\begin{tabular}{|c|c|c|c|c|c|c|}
\hline Silage additive... & NA & FA & LFA & E & SEM & $\begin{array}{l}\text { Statistical } \\
\text { significance } \\
\text { of additive }\end{array}$ \\
\hline
\end{tabular}

Organic matter

Rumen degradation parameters

$\begin{array}{ccccrrr}\text { a } & 0.240 & 0.165 & 0.192 & 0.227 & 0.0212 & \text { NS } \\ \text { b } & 0.622 & 0.685 & 0.659 & 0.626 & 0.0196 & \text { NS } \\ \text { a+b } & 0.862 & 0.850 & 0.851 & 0.853 & 0.0038 & \text { NS } \\ \text { c } & 0.062 & 0.058 & 0.056 & 0.064 & 0.0059 & \text { NS } \\ \text { Lag time (h) } & 1.7 & 1.8 & 1.9 & 2.3 & 0.59 & \text { NS }\end{array}$

Degradability of feed

$\begin{array}{lllllll}\text { in the rumen } f & 0.720 & 0.685 & 0.695 & 0.703 & 0.0160 & \text { NS } \\ \text { in the intestine } \S & 0.102 & 0.112 & 0.102 & 0.112 & 0.0076 & \text { NS } \\ \text { in the total tract } & 0.749 & 0.720 & 0.727 & 0.737 & 0.0132 & \text { NS }\end{array}$

Neutral detergent fibre

Rumen degradation parameters

\begin{tabular}{|c|c|c|c|c|c|c|}
\hline a & -0.035 & -0.110 & -0.091 & -0.133 & 0.0274 & NS \\
\hline b & 0.842 & 0.902 & 0.882 & 0.910 & 0.0251 & NS \\
\hline $\mathrm{a}+\mathrm{b}$ & $0.807 b$ & $0.792 \mathrm{ab}$ & $0.791 \mathrm{ab}$ & $0.777 \mathrm{a}$ & 0.0050 & * \\
\hline c & 0.059 & 0.057 & 0.054 & 0.062 & 0.0054 & NS \\
\hline ag time (h) & 2.0 & 2.1 & 2.2 & 2.9 & 0.45 & NS \\
\hline $\begin{array}{l}\text { egradability of } \\
\text { in the rumen } f\end{array}$ & 0.592 & 0.556 & 0.554 & 0.542 & 0.0254 & NS \\
\hline in the intestine $\$$ & 0.061 & 0.064 & 0.063 & 0.063 & 0.0065 & NS \\
\hline in the total tract & 0.614 & 0.584 & 0.581 & 0.574 & 0.0228 & NS \\
\hline
\end{tabular}

Nitrogen

Rumen degradation parameters

\begin{tabular}{|c|c|c|c|c|c|c|}
\hline a & 0.435 & 0.315 & 0.398 & 0.452 & 0.0436 & NS \\
\hline b & 0.487 & 0.607 & 0.528 & 0.468 & 0.0378 & NS \\
\hline$a+b$ & 0.922 & 0.922 & 0.926 & 0.920 & 0.0079 & NS \\
\hline c & 0.085 & 0.072 & 0.074 & 0.077 & 0.0071 & NS \\
\hline EPD† & 0.779 & 0.730 & 0.757 & 0.777 & 0.0123 & NS \\
\hline EPD $\neq$ & $0.912 b$ & $0.875 \mathrm{a}$ & $0.896 b$ & $0.912 b$ & 0.0047 & *** \\
\hline ag time (h) & 4.1 & 1.9 & 1.8 & 2.0 & 1.07 & NS \\
\hline \multicolumn{7}{|c|}{ egradability of feed } \\
\hline n the intestine $\S$ & 0.541 & 0.566 & 0.527 & 0.564 & 0.0205 & NS \\
\hline $\mathrm{n}$ the total tract & 0.939 & 0.926 & 0.927 & 0.931 & 0.0045 & NS \\
\hline
\end{tabular}

For silage additives, see text.

$f$ Incubated in the rumen for $30 \mathrm{~h}$.

$\S$ To prepare the rumen undegraded feed residue rumen incubation period of $30 \mathrm{~h}$ was used.

$\dagger$ Effective protein degradability calculated with $\mathrm{k}=0.033$.

$\ddagger$ EPD corrected for microbial contamination as suggested by LINDBERG (1988).

a,b Means in the same row with different superscripts were significantly different $(\mathrm{P} \leq 0.05)$.

NS, not significant; ${ }^{*}, \mathrm{P} \leq 0.05 ;{ }^{* * *}, \mathrm{P} \leq 0.001$. 


\section{Rumen fermentation and liquid dilution rate}

The average rumen $\mathrm{pH}$ was not affected by the silage additive (Table 6). The concentration of ammonia- $\mathrm{N}$ in the rumen was significantly $(\mathrm{P}<0.05)$ higher for LFA and NA diets as compared to the other diets.

The concentration of total VFA was not affected by the silage additive, but the molar proportion of acetate was significantly $(\mathrm{P}<0.001)$ higher and that of propionate lower with FA and LFA than with E and NA silages (Table 6). The proportion of buty- rate was significantly higher with $\mathrm{E}$ treatment compared to the others. Statistically significant differences between the curve patterns were not found for any of the fermentation parameters measured.

The liquid dilution rate tended to be higher with FA and LFA silages compared to NA and E silages (Table 7). The estimate of rumen volume was smallest with E silage and largest with NA silage. The liquid outflow rate from the rumen was slowest with $\mathrm{E}$ silage, the value being significantly $(\mathrm{P}<0.05)$ different from those with LFA and NA silages.

Table 6. The effect of silage additive on rumen fermentation.

\begin{tabular}{|c|c|c|c|c|c|c|}
\hline Silage additive... & NA & FA & LFA & $\mathrm{E}$ & SEM & $\begin{array}{l}\text { Statistical } \\
\text { significance } \\
\text { of additive }\end{array}$ \\
\hline $\mathrm{pH}$ & 6.75 & 6.73 & 6.80 & 6.73 & 0.065 & NS \\
\hline Ammonia $\mathrm{N}(\mathrm{mmol} / \mathrm{l})$ & $8.88 \mathrm{~b}$ & $8.86 \mathrm{~b}$ & $10.51 \mathrm{a}$ & $10.17 \mathrm{a}$ & 0.969 & $* * *$ \\
\hline Total VFA (mmol/l) & $96.9 \mathrm{~b}$ & 100.3 & 97.4 & 100.0 & 3.76 & NS \\
\hline \multicolumn{7}{|l|}{$\begin{array}{l}\text { Molar proportion of } \\
\text { VFAs }(\mathrm{mmol} / \mathrm{mol})\end{array}$} \\
\hline Acetic acid & $655 \mathrm{~b}$ & $695 \mathrm{a}$ & $690 \mathrm{a}$ & $649 \mathrm{~b}$ & 7.5 & $* * *$ \\
\hline Propionic acid & $221 \mathrm{a}$ & $169 \mathrm{~d}$ & $181 \mathrm{c}$ & $206 \mathrm{~b}$ & 7.9 & $* * *$ \\
\hline Butyric acid & $96 \mathrm{c}$ & $107 \mathrm{~b}$ & $96 \mathrm{c}$ & $112 \mathrm{a}$ & 3.3 & $* * *$ \\
\hline Isovaleric acid & $18.1 \mathrm{~b}$ & $18.8 \mathrm{cb}$ & $22.2 \mathrm{a}$ & $20.6 \mathrm{ab}$ & 1.87 & $* * *$ \\
\hline Valeric acid & $10.8 \mathrm{~b}$ & 10.8 & 11.9 & 11.5 & 1.24 & NS \\
\hline Ratio $(\mathrm{Ac}+\mathrm{Bu}) / \mathrm{Pr}$ & $3.5 \mathrm{~d}$ & $4.8 \mathrm{a}$ & $4.4 \mathrm{~b}$ & $3.8 \mathrm{c}$ & 0.19 & $* * *$ \\
\hline Ratio $\operatorname{Pr} / \mathrm{Bu}$ & $2.4 \mathrm{a}$ & $1.6 \mathrm{c}$ & $1.9 \mathrm{~b}$ & $1.9 \mathrm{~b}$ & 0.12 & $* * *$ \\
\hline
\end{tabular}

For silage additives, see text.

Ac, acetic acid; Pr, propionc acid; Bu, butyric acid.

a,b,c,d Means in the same row with different superscripts were significantly different $(\mathrm{P} \leq 0.05)$.

NS, not significant; ${ }^{* * *}, \mathrm{P} \leq 0.001$.

Table 7. The effect of silage additive on rumen outflow rate (D), rumen volume and liquid outflow in cattle.

\begin{tabular}{lcccccc}
\hline Silage additive... & NA & FA & LFA & E & SEM & $\begin{array}{l}\text { Statistical } \\
\text { significance } \\
\text { of additive }\end{array}$ \\
\hline Liquid D (1/h) & 0.075 & 0.092 & 0.091 & 0.082 & 0.0054 & NS \\
Rumen volume (1) & 54.6 & 46.6 & 46.9 & 40.1 & 3.83 & NS \\
Liquid outflow (1/d) & $95.6 \mathrm{~b}$ & $91.8 \mathrm{ab}$ & $98.7 \mathrm{~b}$ & $75.3 \mathrm{a}$ & 3.91 & $*$ \\
\hline
\end{tabular}

For silage additives, see text.

a,b Means in the same row with different supercripts were significantly different $(\mathrm{P} \leq 0.05)$.

NS, not significant; ${ }^{*}, \mathrm{P} \leq 0.05$. 


\section{Discussion}

\section{Silage quality}

In accordance with previous results (HENDERSON et al. 1982, KENNEDY 1990, HEIKKILĀ et al. 1989, VAN VUUREN et al. 1989, JAAKKOLA 1990, JAAKKOLA et al. 1990, JACOBS and MCAlLAN 1991, HEIKKILÄ et al. 1991), the cell wall content of E silage found to be clearly reduced compared to others indicating the activity of enzymes to hydrolyze cell walls to WSC.

Dry matter content was highest in FA silage reflecting higher effluent losses compared to those from other silages (4.1 vs. average $1.7 \% \mathrm{DM}$, see TOIVONEN 1989). The E and NA silages were notably more fermented than the LFA and especially FA silages preserved with acid-based additives. Similar differences between silages have been found in previous comparative studies (RAURAMAA et al. 1987, JAAKKOLA et al. 1991, JACOBS and MCALLAN 1991). In accordance with RAURAMAA et al. (1987), only minor differences in fermentation patterns were found between $\mathrm{E}$ and NA silage. However, the use of enzymes in silage making especially under poor weather conditions has resulted in more favourable fermentation than in ensiling without additives (JAAKKOLA 1990, JAAKKOLA et al. 1991). Obviously the use of pilot silos in making the experimental silages resulted in good-quality fermentation in NA silage, too.

\section{Digestion of organic matter and fibre}

The proportion of digestible OM apparently digested before the intestine was rather low (average 0.52 ) and the total $\mathrm{N}$ entering the duodenum was rather high (Tables 3 and 4). These values may be affected by duodenal digestive juices, since the duodenal cannulas were checked at slaughter and found to be located posterior to the pancreatic duct. However, the disappearance of digestible fibre before the small intestine indicated no overestimation (Table 3). Hence, the possible contamination should have no influence on the comparison of the treatments.

JAAKKOLA et al. (1991) could find no marked improvements in the digestibility of grass silage OM through the use of cell wall degrading enzymes. However, in the present study, in agreement with the experiment of JACOBS et al. (1991) with growing steers, the $\mathrm{OM}$ digestibility of $\mathrm{E}$ silage was significantly higher than that of untreated or acid treated silages (Table 3). In accordance with the results of JAAKKOLA et al. (1991), the digestibility of cell walls also tended to be higher for the E silage diet as compared to the others. Several previous reports have pointed out that enzyme treatment impaired rather than improved the fibre digestibility of grass silage with sheep (HEIKKILÄ et al. 1989, TOIVONEN 1989, JAAKKOLA 1990, HeIKKILÄ et al. 1991), and also with growing cattle (JAAKKOLA and HUHTANEN 1990, JAAKKOLA et al. 1990).

It has been suggested that the higher digestibility of cellulose in E silage compared to FA and NA silages with cattle is a consequense of a longer rumen residence time (RRT) (JAAKKOLA et al. 1991). A longer rumen retention time has been observed for cattle given forage diets than for sheep (REes and LitTLE 1980), especially at low levels of feeding (ColucCl et al. 1984).

The RRT of the silages was not measured in the present experiment, but as the proportion of digestible OM and NDF digested in the rumen was highest with E silage, the higher digestibility of E silage may be related to possible differences in RRT between the silages. The contradiction in results between the experiments may be related at least partly to the different feeding levels. In the present experiment, the cattle were fed near maintenance level in contrast to experiments performed with growing cattle, or with another species, sheep.

\section{Digestion of nitrogen}

The NAN flow entering the duodenum was significantly lower with the $\mathrm{E}$ diet than the other diets (Table 4), mainly due to the significantly lower feed $\mathrm{N}$ flow. The flow of microbial $\mathrm{N}$ was clearly highest for the LFA diet. In the study of JACOBS and 
MCALlan (1991), the flow of nitrogenous compounds was similar for untreated, FA and enzyme silages. On the other hand, JAAKKOLA et al. (1991) found that the quantity of microbial $\mathrm{N}$ entering the duodenum was significantly higher with FA silage than with E silage. The contradiction between the experiments may be due to the different application rate of formic acid used, resulting in differences in the extent of fermentation. When feeding restrictively fermented silages, more fermentable carbohydrates are available for rumen microbes than from extensively fermented silages (CHAMBERLAIN 1987). This is possibly one reason for the higher microbial $\mathrm{N}$ obtained with the LFA diet in the present experiment. The advantage of restricted fermentation of FA silage in the present experiment was probably lost because of considerable effluent losses in the silo (ToIVONEN 1989) due to the reduced moisture-holding capacity of FA silage (WOOLFORD 1978).

Supplementation of grass silage with concentrate has generally increased the efficiency of microbial protein synthesis in the rumen (ARC 1984). The present average efficiency of $30 \mathrm{~g}$ microbial N/organic matter apparently digested in the rumen (OMARD) is consistent with the value given for similar feeding by ARC (1984). The lowest efficiency, which was obtained for the E diet (Table 3), contrasts with the results of JACOBS and MCALLAN (1989, 1991), who reported higher efficiency for E feeding compared with FA feeding, especially when the E diet was supplemented with rapeseed meal. JACOBS and MCALLAN (1989) concluded that enzyme treatment of the grass during ensiling had a marked effect on the availibility or utilizability of structural carbohydrates. Nevertheless, the present results rather support the suggestion by JAAKKOLA et al. (1991) that not even a high-quality supplement compensates for the difference in silage quality caused by lactic acid fermentation.

\section{Degradability of silages in the rumen and the intestine}

Compared with the acid-based additives, the E additive tended to increase the instantly degradable fraction $a$ of $\mathrm{OM}$ and $\mathrm{N}$ of $\mathrm{E}$ with no effect on potential degradation, but it decreased the potential degradability of the cell walls. This finding was in line with the earlier results of HUHTANEN et al. (1985) and VAN VUUREN et al. (1989) indicating that the breakdown of cell walls occurs in the silo rather than in the rumen.

The EPD values and rate of degradation $c$ of silages preserved with acid additives tended to be lower than those of other silages, in accordance with the results of SETÄLÄ et al. (1985) and VIK-Mo (1989) which indicate that the rate of crude protein degradability was regulated mainly by the proteolysis in the silage. Nevertheless, the EPD values of grass silages were high and the correction for microbial contamination still increased them notably, in agreement with the results of LINDBERG (1988). This emphasizes the need to take the correction into account when calculating the EPD values of forages. The degradability of silage- $\mathrm{N}$ in vivo (Table 4) was notably lower than the respective values obtained with the nylon bag method. As the in vivo value was calculated by difference, possible errors in the determination of microbial or endogenous $\mathrm{N}$ will be accumulated in the fraction of feed N. However, both methods ranked the value for FA silage as lowest.

Intestinal OM, NDF and $\mathrm{N}$ degradability of rumen-undegraded feed was rather low regardless of the additive used, on an average $10.7 \%$ for OM, $6.3 \%$ for NDF and $55.0 \%$ for N. In a previous experiment (VARVIKKO and VANHATALO 1988), the respective value for grass silage $\mathrm{N}$ was also low, 57 $\%$ on an average, suggesting that the values used in protein evaluation systems, e.g. $85 \%$ by ARC (1984), overestimate the intestinal degradability of grass silage $\mathrm{N}$.

\section{Rumen fermentation and liquid dilution rate}

Consistent with the results of GORDON (1989), but not with those of JAAKKOLA et al. (1991), the molar proportion of acetate in the rumen fluid was found to be significantly higher with acid-treated silages 
than with E or NA silages. In accordance with previous reports (GORDON 1989, JAAKKOLA et al. 1991), the molar proportion of propionate in the rumen fluid was significantly higher in E and NA feeding, i. e., in silages with a high content of lactic acid, than in FA and LFA feedings. Actually, the propionate increased along with the increasing lactate content in the silage, indicating the conversion of silage lactate to propionate in the rumen (Chamberlain et al. 1983, Newbold et al. 1987, JAAKKOLA and HuHTANEN 1989). Contrary to the results of Gordon (1989) and JAAKKOLA et al. (1991), the proportion of butyric acid for diet $\mathrm{E}$ was higher than for diet FA. When compared with untreated silage, a small increase in the proportion of butyric acid was found with E silage (VAN VUUREN et al. 1991). However, the changes in rumen VFAs found in the present experiment were commensurate to the reduction in milk fat content with E silage feeding compared to FA silage feeding in dairy cows (HEIKKILÄ et al. 1989, 1991).

Again in contrast to previous results (JAAKKOLA et al. 1991, JACOBS and MCALLAN 1991), the liquid dilution rate, rumen volume and liquid outflow rate from the rumen were different for the E diet compared to the other diets in the present study. However, also in the experiment by JACOBS and MCALLAN (1991), the estimated rumen volume tended to be smaller for the E diet compared to the FA and NA diets. The liquid dilution rate did not seem to be associated with microbial protein synthesis either in this study or in the study by JAAKKOLA et al. (1991), even though the differences between the diets in synthesized microbial protein were quite clear in both of experiments.

In conclusion, acid-based additives resulted in more restricted fermentation during ensiling than did enzymes or the absence of additive. The improved $\mathrm{OM}$ and cell wall digestibility in vivo of the $\mathrm{E}$ diet as compared to the other diets were obviously a consequence of the low feeding level in the present experiment. The highest efficiency of microbial protein synthesis in the rumen obtained for LFA feeding was attributed to the small effluent losses and the restricted fermentation of silage in the silo. Regardless of the additive used, the EPD values of the silages were high, especially when corrected for microbial contamination, and the values for intestinal degradation of rumenundegraded $\mathrm{N}$ were low compared to the values used in protein evaluation systems.

Acknowledgements. The financial contribution by the Finnish feed industry towards carrying out this experiment is gratefully acknowledged. The authors are also indebted to Ms. Aino Matilainen for her technical assistance in the study.

\section{References}

ARC 1984. The nutrient requirements of ruminant livestock. Supplement 1. Agricultural Research Council. Commonwealth Agricultural Bureaux; Farnham Royal, Slough.

BARKer, S.B. \& Summerson, W.H. 1941. The colorimetric determination of lactic acid in biological material. J. Biol. Chem. 138: 535-554.

Chamberlain, D.G., Thomas P.C. \& Anderson F.J. 1983. Volatile fatty acid proportions and lactic acid metabolism in the rumen in sheep and cattle receiving silage diets. J. Agric. Sci. Camb. 101: 47-58.

- 1987. The silage fermentation in relation to utilization of nutrients in the rumen. Proc. Biochem. 22: 60-63.

Colucci, P.E.G. \& MacLeod, W.L., Grovum, W.L. \& MCMILlan, I. 1984. Comparative digestion and digesta kinetics in sheep and cattle. Can. J. Anim. Sci. 64 (Suppl.): 173.
FAICHNEY, G.H. 1975. The use of markers in partitioning digestion within gastrointestinal tract of ruminants. In: Mc Donald, I.W. \& Warner, A.C.I. (eds.). Digestion and metabolism in ruminant. The University of New England Pub. Unit. Sydney. pp. 277-291.

Gordon, F.J. 1989. A further study on the evaluation through lactating cattle of a bacterial inoculant as an additive for grass silage. Grass and Forage Sci. 44: 353357.

HeIKKILĀ, T., VÃÃTÃINEN, H. \& LAMPILA, M. 1989. Effect of silage quality on milk yield and composition in dairy cows. International symposium on production, evaluation and feeding of silage. Rostock, DDR. pp. 177-183.

—, TOIVONEN, T. \& VÄÃTÄInEN, H. 1991. Effect of biological additives on silage quality and milk production with dairy cows. 42 nd Annual Meeting of the EAAP. Berlin, Germany. Vol. 2. p. 49. 
Henderson, A.R., McDonald, P. \& Henderson, D. 1982. The effects of a cellulase preparation derived from Trichoderma viride on the chemical changes during the ensilage of grass, lucerne and clover. J. Sci. Fd Agric. 33: 16-20.

Huhtanen, P., Hissa, K., JaAkKola, S. \& Poutiainen, E. 1985. Enzymes as silage additive. Effect on fermentation quality, digestibility in sheep, degradability in sacco and performance in growing cattle. J. Agric. Sci. Finl. 57: 284-292.

HuIDA, L. 1973. Haihtuvien rasvahappojen kvantitatiivinen määrittäminen pötsinesteestä ja säilörehusta kaasukromatografisesti. Quantitative determination of volatile fatty acids from rumen sample and silage by gas-liquid chromatography. J. Scient. Agric. Soc. Fin. 45: 483-488.

—, VÄÄTÄINEN, H. \& LAMPILA, M. 1986. Comparison of dry matter contents in grass silages as determined by oven drying and gas chromatographic water analysis. Ann. Agric. Fenn. 25: 215-230.

JAAKKOLA, S. 1990. The effect of cell wall degrading enzymes on the preservation of grass and on the silage intake and digestibility in sheep. J. Agric. Sci. Finl. 62: 51-62.

- \& Huhtanen, P. 1989. The effect of lactic acid on the microbial protein synthesis in the rumen of cattle. AsianAustralasian, Journal of Animal Sciences 3: 398-399.

- \& Huhtanen, P. 1990. The response to cellulase treatment of silage and replacement of barley by unmolassed sugar beet pulp in the diets of growing cattle. Acta Acrig. Scand. 40: 415-426.

-, Huhtanen, P. \& Vanhatalo, A. 1990. Fermentation quality of grass silage treated with enzymes or formic acid and nutritive value in growing cattle fed with or without fish meal. Acta Acrig. Scand. 40: 403-414.

-, Huhtanen, P. \& Hissa, K. 1991. The effect of cell wall degrading enzymes or formic acid on fermentation quality and on digestion of grass sillage by cattle. Grass and Forage Sci. 46: 75-87.

JACOBS, J.L. \& MCAllan, A.B. 1989. Enzyme additives for silage. Duodenal nitrogenous constituents flow and weight gains in growing steers. Asian-Australasian Journal of Animal Sciences 3: 338-339.

—, COOK, J.E. \& McAllan, A.B. 1991. Enzymes as silage additives 2 . The effect of grass dry matter content on silage quality and performance on sheep. Grass and Forage Sci. 46: 191-199.

-, Haines, M.J. \& McAllan, A.B. 1990. The effects of different protein supplements on the utilization of untreated, formic acid or enzyme treated silages by growing steers. Proceedings of the Ninth Silage Conference. Faculty of Agriculture University of Newcastle upon Tyne. p. 58-59.

— \& McAllan, A.B. 1991. Enzymes as silage additives. 1. Silage quality, digestion, digestibility and performance in growing cattle. Grass and Forage Sci. 46: 61-73.

KENNEDY, S.J. 1990. An evaluation of three bacterial inocu- lants and formic acid as additives for first harvest grass. Grass and Forage Sci. 45: 281-288.

LINDBERG, J.E. 1988. Influence of cutting time and $\mathrm{N}$ fertilization on the nutritive value of timothy. 2. Estimates of rumen degradability of nitrogenous compounds. Swe. J. Agric. Res. 18: 85-89.

MCAllan, A.B. \& SMITH, R.H. 1983. Factors affecting the digestion of dietary carbohydrates between the mouth and duodenum. Br. J. Nutr. 50: 445-454.

McCullough, H. 1967. The determination of ammonia in whole blood by direct colorimetric method. Clin. Chem. Acta 17: 297-304.

MCDonalD, I. 1981. A revised model for the estimation of protein degradability in the rumen. J. Agric. Sci. Camb. 96: 251-252.

Newbold, C.J., Williams, A.G. \& Chamberlain, D.G. 1987. The in vitro metabolism of D, L-lactic acid by rumen micro-organisms. J. Sci. Fd Agric. 38: 9-18.

RauramaA, A., Setälä, J., Moisıo, T., Heikkilä, T. \& LAMPILA, M. 1987. The effect of inoculants and cellulase on the fermentation and microbiological composition in grass silage. 1. Biochemical changes in the silages. J. Agric. Sci. Finl. 59: 361-370.

ReEs, M.C. \& LitTle, D.A. 1980. Differences between sheep and cattle in digestibility, voluntary intake and retention time in the rumen of three tropical grasses. J. Agric. Sci. Camb. 94: 483-485.

SAlo, M.-L., TuORI, M. \& KIISKINEN, T. 1982. Rehutaulukot ja ruokintanormit. 70 p. Helsinki.

Setälä, J., Tesfa, A., RauramaA, A. \& Poutiainen, E. 1985. Factors affecting in sacco degradation of dry matter and crude protein in grass silage. J. Agric. Sci. Finl. 57: 139-146.

SomogYI, M. 1945. A new reagent for the determination of sugars. J. Biol. Chem. 160: 61-68.

TAmminga, S., Robinson, P.H., Vogt, M. \& Boer, H. 1989. Rumen ingesta kinetics of cell wall components in dairy cows. Anim. Feed Sci. Technol. 25: 89-98.

TorvONEN, V. 1989. Additives and the quality of silage. International symposium on production, evaluation and feeding of silage, Rostock, DDR. pp. 65-67.

UdÉn, P., Colucci, P.E. \& VAN SOEST, P.J. 1980. Investigation of chromium, cerium and cobalt as markers in digesta. Rate of passage studies. J. Sci. Fd Agric. 31: 625-632.

Van Keulen, J. \& Young, B.A. 1977. Evaluation of acidinsoluble ash as a natural marker in ruminant digestibility studies. J. Anim. Sci. 44: 282-287.

VAN SOEST, P.J. 1963. Use of detergents in the analysis of fibrous feeds. II. A rapid method for the determination of fibre and lignin. J. A. O. A. C. 46: 829-835.

— \& WINE, R.H. 1967. Use of detergents in the analysis of fibrous materials. IV. Determination of plant cell wall constituents. J. A. O. A. C. 50: 50-55.

Van Vuuren, A.M., Bergsma, K., Frol-Kramer, F. \& BEERS, J.A.C. 1989. Effects od addition of cell wall de- 
grading enzymes on the chemical and the in sacco degradation of grass silage. Grass and Forage Sci. 44: 223230.

-, van der Koelen, C.J. \& BeuvinK, J.M.W. 1991. Effect of treatment of silages with cell wall degrading enzymes on rumen fermentation and digesta kinetics in dairy cows receiving complete mixed diets based on grass silage. Forage conservation towards 2000. A Conference of the European Grassland Federation. Braunschweig, Germany, pp. 118-119.

VARViKKo, T. \& VANhatalo, A. 1988. Intestinal nitrogen degradation in sacco of hay and grass silage. Proceedings VI World Animal Conference on Animal Production, Helsinki. p. 359. Jyväskylä: Gummerus Oy kirjapaino.

VIK-Mo, L. 1989. Degradability of forages in sacco. 2. Silages of grassses and red clover at two cutting times, with formic acid and without additive. Acta Agric. Scand. 39: 53-64.
Williams, C.H., David, D. \& RiISmaA, O. 1962. The determination of chromic oxide in faeces samples by atomic absorption spectrometry. J. Agric. Sci. Camb. 59: 381 385 .

WoOLFORD, M.K. 1978. The problem of silage effluent. Herbage Abstracts 48: 397-403.

ZINN, R.A. \& OWENS, F.N. 1986. A rapid procedure for purine measurements and its use for estimating net ruminal protein synthesis. Can. J. Anim. Sci. 66: 157-166.

\section{Manuscript received December 1991}

Aila Vanhatalo

Tuomo Varvikko

Ilmo Aronen

Agricultural Research Centre of Finland

Institute of Animal Production

SF-31600 Jokioinen, Finland

\title{
SELOSTUS
}

\section{Eri säilöntäaineiden vaikutus säilörehun laatuun sekä säilörehudieetin sulavuuteen, mikrobisynteesiin ja pötsifermentaatioon naudalla}

\author{
Aila Vanhatalo, Tuomo Varvikko ja Ilmo Aronen \\ Maatalouden tutkimuskeskus
}

Tutkimuksessa verrattiin eri säilöntäaineilla valmistettujen säilörehujen vaikutusta naudan pötsifermentaatioon, ravintoaineiden virtaukseen ohutsuoleen ja mikrobisynteesiin. Săilörehut tehtiin koiranheinä-timotei-nurmen toisesta sadosta seuraavilla säilöntäaineilla: ilman säilöntäainetta (NA), muurahaishappo (FA), lignosulfonaattien, muurahaisja etikkahapon seos (LFA) ja sellulaasia ja glukoosioksidaasia sisältävă entsyymiseos (E). Koe-eläiminä oli neljă ylläpitotasolla ruokittua pötsi- ja ohutsuolifistelöityä hiehoa (elopaino $550 \mathrm{~kg}$ ). Koe järjestettiin $4 \times 4$ latinalaisen neliön mukaan ja koeruokintoihin sisältyi tutkittavan säilörehun lisäksi väkirehua (ohra-kaura 1:1) $30 \%$ dieetin kuivaaineesta.

Kaikki säilörehut olivat hyvälaatuisia, mutta hapoilla säilötyt rehut olivat văhemmän käyneită kuin entsyymi- ja pai- norehu. Entsyymirehun kuitupitoisuus oli alempi kuin muiden rehujen. E dieetin orgaanisen aineen ja kuidun năennäiset sulavuudet olivat merkitsevästi korkeampia $(\mathrm{P}<0.05)$ kuin muiden dieettien. Mikrobivalkuaisen virtaus ohutsuoleen oli merkitsevästi korkeampi $(\mathrm{P}<0.001)$ LFA dieetillä (NA 52; FA 53; LFA 66 ja E $47 \mathrm{~g} \mathrm{~N} / \mathrm{d}$ ) ja mikrobisynteesin tehokkuus alempi $\mathrm{E}$ dieetillä muihin verrattuna (NA 31; FA 31; LFA 38 ja E 20 g N / pötsissä näennäisesti sulanut orgaaninen aine). Etikkahapon osuus pötsin haihtuvista rasvahapoista oli FA ja LFA dieeteillä merkitsevästi korkeampi $(\mathrm{P}<0.001)$ ja propionihapon osuus merkitsevästi alempi $(\mathrm{P}<0.001)$ kuin $\mathrm{E}$ ja NA dieeteillä. Voihapon osuus oli $\mathrm{E}$ dieetillä merkitsevästi $(\mathrm{P}<0.001)$ muita korkeampi. 